\title{
RETAIL BANK LENDING: DEBT BURDEN IS DECREASING ${ }^{1}$
}

\section{M.Khromov}

In 2016, the volume of bank lending resumed growth. However, its level remains below the 2014 indicators and is insufficient to curtail the reduction of the population's loan debt volumes. There is a shift in the retail bank lending debt structure in favor of the long-term and cheaper mortgages. This results in the reduction of the debt burden on the disposable income of the households.

In Q1 2016, the volumes of the retail bank lending commenced recovering following a sharp fall in 2015. The amount of loans extended by the banks to the households over first three months of 2016 constituted Rb 1.5 trillion, which is by $36 \%$ more than a year earlier (Rb 1.1 trillion). More growth was observed in the housing mortgage, which volumes went up by $46 \%$ from $\mathrm{Rb}$ 223bn in Q1 2015 to Rb 326bn in Q1 2016. Other types of loans extension movement was more moderate. Their volume in Q1 2016 moved up by 33\% in comparison with the corresponding period of 2015.

Despite rather intensive growth of loans origination (comparable with level of movement was representative, for instance, of 2012 when retail lending was actively unfolding), proper lending volumes have not yet recovered following last year slump. Due to sharp fall in 2015, the volumes of loan origination have not yet achieved the 2014 level as of their nominal value. Aggregate volume of extended loans in Q1 2016 tuned out to be $22 \%$ less than in Q1 2014. Even in housing lending where the reduction in 2015 was minimal and growth in 2016 was maximum, volumes of extended loans in Q1 2016 remained by $6 \%$ below than in the corresponding period of 2014.

The fact that the nominal volume of lending is remaining as a rather low level means that its impact on the financial balance of the households has failed to recover much less. For example, in Q1 2014, the volume of the volume of extended by the banks new loans to the households was comparable with $20 \%$ of their money income. Due to meltdown of the credit market, which happened at the beginning of 2015, this ratio as of the period-end for Q1 2015 fell to 10\%. And in Q1 2016, the volume of extended new bank loans increased barely to $13 \%$ of the money income of the households.

The low level of new loans origination predetermines continuation of the aggregate household bank debt contraction. This is due to the fact that the volumes of actual loan repayments have decreased insignificantly compared to the reduction of the new loans origination. In Q1 2016, as in the same period of 2015 , the households spent around $14 \%$ of their money income on bank loans repayments, meanwhile in Q1 2016, this ratio amounted to $17 \%$.

Reduction of total household outstanding debt on bank loans ${ }^{2}$ has been continuing since December 2014. During this period, the retail credit port-

1 This paper was originally published in Online Monitoring of Russia's Economic Outlook No.9(27).

2 Adjusted to revaluation of debt denominated in foreign currency. 
folio of banks has shrunk by $7 \%$ and the ration of the aggregate debt volume to the money income of the population over 12 months has contracted by 4 p.p. - from $23.6 \%$ to $19.6 \%$. This is one of the factors, which is driving the credit burden on the population's income down.

A shift in the loan debt pattern in favor of long-term and cheaper residential mortgage loans can be viewed as a positive trend in addition to a reduction of relative volume of debt volume. Following the results of Q1 2016, the share of loans extended on purchase of housing reached $39 \%$ of the total volume of the household bank debt. Meanwhile, in late 2014 this indicator barely exceeded $30 \%$. Increment of the share of long-term loans means that with the same volume of debt the borrowers have to repay less on the principal debt, which reduces the volume of mandatory payments.

At the same time, mortgage portfolio as well as other loans portfolio duration according to the principal debt service figure has noticeably grown over the last year. If at the early 2015 , weighted average term of the total debt constituted 38-40 months

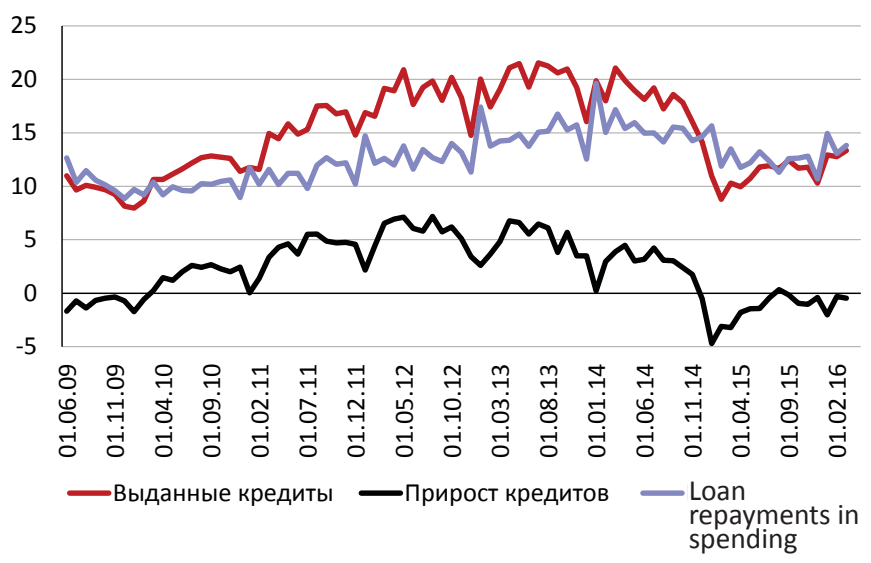

Sources: Bank of Russia, Rosstat, and IEP estimates.

Fig. 1. Parameters of the retail bank lending in $\%$ to the money income of the households, 2009-2016

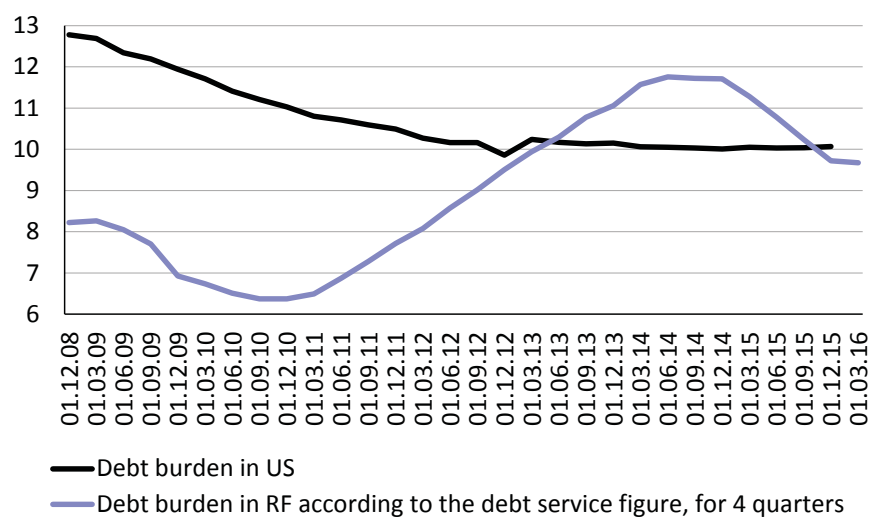

Sources: Federal Reserve, Bank of Russia, Rosstat, and IEP estimates.

Fig. 2. Debt burden on disposable income in RF and US and the mortgage debt - 94-98 months, then in early 2016 these indicators went up to $46-48$ months for total debt and 148-150 months for the residential mortgage loans.

Weighted average cost of the household outstanding debt has not changed over the year. In Q1 2015, it amounted to 16.4\% per year, and in Q1 2016, went up to $16.5 \%$ per year. Such stability is due to the growth of the share of residential mortgage loans, which cost remains noticeably lower: $12.5 \%$ per year in Q1 2015 and $12.6 \%$ per year in the same period of 2016 . At the same time, the cost of other loans moved up more for a year - from $18.4 \%$ to $19.0 \%$ per annum.

All enumerated above factors lead to a gradual reduction of the debt burden on the household disposable income observable since the second half of 2014. Then, the households allocated on service of their credit debt up to $11.8 \%$ of disposable income. By the period-end for Q1 2016, the debt burden decreased to $9.7 \%$ of the disposable income.

If we compare the Russian lending market, for example, with the US lending market, then the Russian households by end-2015 came up with the American households on the debt burden parameter. However, the debt level against income for American households exceeds $100 \%$, which is 5 -fold exceeds the Russian level with the comparable level of debt burden. 